\title{
The Effect of Community Health Center on Visual Acetic Acid Uptake in Pati, Central Java
}

\author{
Retno Wulan'), Pawito), Bhisma Murti1) \\ 1)Masters Program in Public Health, Universitas Sebelas Maret \\ ${ }^{2)}$ Faculty of Social and Political Sciences, Universitas Sebelas Maret
}

\begin{abstract}
Background: Cervical cancer is included in the category of malignant tumors that arise in the cervix of women. The incidence of cervical cancer is high due to lack of awareness to make efforts to examine early detection of cervical cancer by using the visual inspection acetic acid (VIA) method. The purpose of this study was to analyze the effect of community health center on the use of VIA.

Subject dan Method: This was an analytic observational study with a cross sectional design. was The study was conducted at 29 community health centers in Pati, Central Java. A sample of 232 women was selected by simple random sampling. The dependent variable was VIA uptake. The independent variable were perceived susceptibility, perceived seriousness, cues to action, perceived threat, perceived benefit, perceived barrier, self-efficacy, economic status, and social capital. The data were collected by questionnaire and analyzed by a multilevel multiple logistic regression run on Stata 13.

Result: Community health center had a contextual effect on VIA uptake with intra-class correlation $(\mathrm{ICC})=16.91 \%$. VIA uptake increased with high perceived susceptibility $(b=3.21 ; 95 \%$ $\mathrm{CI}=0.22$ to $6.19 ; \mathrm{p}=0.035)$, high perceived seriousness $(\mathrm{b}=4.68 ; 95 \% \mathrm{CI}=1.06$ to $8.29 ; \mathrm{p}=0.011)$, high perceived threat $(\mathrm{b}=4.03 ; 95 \% \mathrm{CI}=0.61$ to $7.45 ; \mathrm{p}=0.021)$, high perceived barrier $(\mathrm{b}=2.48$; $95 \% \mathrm{CI}=0.06$ to $4.91 ; \mathrm{p}=0.044)$, high perceived benefit $(\mathrm{b}=2.50 ; 95 \% \mathrm{CI}=0.10$ to $4.91 ; \mathrm{p}=0.041)$, and high economic status ( $\mathrm{b}=11.22 ; 95 \% \mathrm{CI}=3.64$ to $18.81 ; \mathrm{p}=0.004)$. VIA uptake decreased with low cues to action $(b=-0.92 ; 95 \% \mathrm{CI}=-3.08$ to $1.24 ; \mathrm{p}=0.405)$, low self-efficacy $(b=-0.32 ; 95 \%$ $\mathrm{CI}=-2.45$ to $1.80 ; \mathrm{p}=0.765)$, and low social capital $(\mathrm{b}=0.79 ; 95 \% \mathrm{CI}=3.64$ to $18.81 ; \mathrm{p}=0.562)$.

Conclusion: Community health center had a contextual effect on VIA uptake. VIA uptake increases with high perceived susceptibility, high perceived seriousness, high perceived threat, high perceived barrier, high perceived benefit, and high economic status. VIA uptake decreases with low cues to action, low self-efficacy, and low social capital.
\end{abstract}

Keywords: Community Community health center, Acetic Acid Visual Inspection.

\section{Correspondence:}

Retno Wulan. Masters Program of Public Health, Universitas Sebelas Maret, JL. Ir.Sutami 36A, Surakarta, Central Jawa, Indonesia. E-mail: wuland.cimmutzz12@gmail.com. Mobile: 085740969271.

\section{BACKGROUND}

Breast cancer and cervical cancer are the most common cancers in the world and in Indonesia. Those cancer are one of the main problems in women's health in the world, especially in developing countries that have limited resources such as in Indonesia. Cancer control, especially breast cancer and cervical cancer, is developed through an early detection program (screening). This program is carried out using the Visual Inspection with Acetic Acid (VIA) and cryotherapy for positive VIA for cervical cancer. Clinical Breast Examination (CBE) and Breast Self-Examination (BSE) are performed for breast cancer (Kementerian Kesehatan RI, 2018). 
Journal of Health Promotion and Behavior (2019), 4(3): 189-199

https://doi.org/10.26911/thejhpb.2019.04.03.04

The percentage of women of reproductive age (WUS) who do early detection of cervical cancer and breast cancer is one indicator of the success of health development as stipulated in the 2014-2019 National Medium Term Development Plan (RPJMN) and Ministry of Health Strategic Plan. The achievement of this indicator is supported by concrete actions in the form of a national movement for the prevention and early detection of cancer in women in Indonesia, which is packaged in the National Program for Increasing Community Participation in the Prevention and Early Detection of Cancer in Women in Indonesia which was announced by the First Lady on April 21, 2015 which then. This movement will last for 5 years. It is expected that in 2019 the number of fertile women that will be detected early will reach 50 percent (Central Java Province Health Office, 2017)

The incidence of cervical cancer is high due to lack of awareness to make efforts to detect cervical cancer early detection and most patients come to the hospital are in an advanced stage. In response to this, there are several tests to early detect cervical cancer, namely HPV tests, pap smear tests, Visual Inspection of Acetic Acid tests (VIA), cervicography, and colposcopy. The VIA method is a method for screening cervical cancer, especially for countries with limited resources (WHO, 2018)

This method has proven its ability to detect cancerous and pre-cancerous lesions. A study was conducted on 2,754 women who carried out VIA showed that $0.8 \%$ women were diagnosed with cervical cancer; $3.5 \%$ high-grade pre-cancerous lesions; and $3.7 \%$ histologically low grade pre-cancerous lesion. The sensitivity of this method is $70 \%$ and the specificity is $79 \%$, it is quite good as a screening tool (Saraswati, 2017).

\section{SUBJECTS AND METHOD}

\section{Study Design}

This was an analytic observation study with a cross sectional design by (Murti (2016). The study was conducted at 29 community health centers in Pati, Central Java, from August to September 2019.

\section{Population dan Sample}

The population in this study were women of childbearing age. A sample of 232 women was selected by simple random sampling.

\section{Study Variables}

The dependent variable was VIA uptake. The independent variables were perceived susceptibility, perceived seriousness, cues to action, perceived threat, perceived benefit, perceived barriers, self-efficacy, economic status, social capital, and at the second level was community health center.

4. Operational Definition of Variables Perceived susceptibility was one's subjective perception of the risk of contracting the disease. The data were collected by questionnaire. The measurement scale was continous, but it was transformed into dichotomous, coded o for $<$ mean and 1 for $\geq$ mean.

Perceived seriousness was a perception of the seriousness of contracting the disease or leaving it untreated. The data were collected by questionnaire. The measurement scale was continous, but it was transformed into dichotomous, coded o for $<$ mean and 1 for $\geq$ mean.

Cues to action was a behavior influenced by something that becomes a signal for someone to do an action or behavior. The data were collected by questionnaire. The measurement scale was continous, but it was transformed into dichotomous, coded o for $<$ mean and 1 for $\geq$ mean. 
Perceived threat was an assumption of vulnerability to an illness and perceived severity. The data were collected by questionnaire. The measurement scale was continous, but it was transformed into dichotomous, coded $\mathrm{o}$ for $<$ mean and 1 for $\geq$ mean.

Perceived benefit was the effectiveness of the level of trust in a strategy designed to reduce the threat of an illness. The data were collected by questionnaire. The measurement scale was continous, but it was transformed into dichotomous, coded o for $<$ mean and 1 for $\geq$ mean.

Perceived barriers was a potential negative consequence that may arise when taking certain actions, including physical, psychological, and financial demands. The data were collected by questionnaire. The measurement scale was continous, but it was transformed into dichotomous, coded o for $<$ mean and 1 for $\geq$ mean.

Self-efficacy was a belief in one's own ability to organize and mobilize the sources of action needed to manage future situations. The data were collected by questionnaire. The measurement scale was continous, but it was transformed into dichotomous, coded $\mathrm{o}$ for $<$ mean and 1 for $\geq$ mean.

Economic status was the position of a person or family in the community based on monthly income. The data were collected by questionnaire. The measurement scale was continous, but it was transformed into dichotomous, coded $\mathrm{O}$ for $<\mathrm{Rp}$ $1,742,000$ and 1 for $\geq$ Rp. 1,742,000.

Social capital was a resource that was owned by the community in the form of norms or values that facilitate and build cooperation through harmonious and conducive networks of interaction and communication. The data were collected by questionnaire. The measurement scale was continous, but it was transformed into dichotomous, coded o for $<$ mean and 1 for $\geq$ mean.

\section{Visual Inspection Acetic Acid Uptake} was measured based on the act of conducting an Acetic Acid Visual Inspection test. The data were collected by questionnaire. The measurement scale was categorical, coded $\mathrm{o}$ for not using the VIA test and 1 for VIA test.

\section{Data Analysis}

Univariate analysis was used to see the frequency distribution and characteristics of study subjects. Bivariate analysis used chisquare test to analyze the association between VIA uptake with independent variables. Multivariate analysis used multilevel multiple logistic regression analysis. The contextual effect of community health center on VIA uptake was shown by the value of intra-class correlations (ICC).

\section{Research Ethics}

This study was conducted based on research ethics, namely informed consent, anonymity, confidentiality, and ethical clearance. Research ethics was obtained from Research Ethics Committee, Dr. Moewardi Hospital, Surakarta, Indonesia, with number: 1.014 / VIII / HREC / 2019.

\begin{tabular}{l}
\hline RESULTS \\
\hline 1. Sample Characteristics \\
The description of categorical data samples \\
explains the continuous data of each study \\
variable including perceived susceptibility, \\
perceived seriousness, cues to action, per- \\
ceived threats, perceived barriers, perceived \\
benefits, self-efficacy, social capital. Sample \\
characteristics were reported in Table 1.
\end{tabular}

\section{Univariate Analysis}

Table 2 shows that women with low perceived susceptibility were 138 (59.8\%), low perceived seriousness were 127 (54.74\%), low perceived threat were 137 (59.05\%), low perceived barrier were 130 (56.03\%), low perceived benefit were 137 (59.05\%), low economic status were 143 (61.6\%), 
Journal of Health Promotion and Behavior (2019), 4(3): 189-199

https://doi.org/10.26911/thejhpb.2019.04.03.04

women who not take VIA test were 154

(66.4\%).

Table 1. Characteristics of study subjects (continuous data)

\begin{tabular}{lccccc}
\hline Variables & n & Mean & SD & Min. & Max. \\
\hline Perceived susceptibility & 232 & 1.74 & 1.43 & o & 4 \\
Perceived seriousness & 232 & 2.39 & 1.55 & o & 5 \\
Cues to action & 232 & 4.07 & 2.52 & o & 10 \\
Perceived threat & 232 & 1.98 & 1.62 & o & 5 \\
Perceived barriers & 232 & 2.84 & 1.93 & 0 & 6 \\
Perceived benefit & 232 & 2.34 & 1.57 & o & 5 \\
Self-efficacy & 232 & 1.94 & 1.45 & o & 4 \\
Social capital & 232 & 4.25 & 2.92 & O & 10 \\
\hline
\end{tabular}

Table 2. Characteristics of the study subjects (categorical data)

\begin{tabular}{lcc}
\hline Variables & $\mathbf{N}$ & $\mathbf{\%}$ \\
\hline Perceived susceptibility & 138 & 59.48 \\
Low & 94 & 40.52 \\
High & & \\
Perceived seriousness & 127 & 54.74 \\
Low & 105 & 45.26 \\
High & & \\
Perceived threat & 137 & 59.05 \\
Low & 95 & 40.95 \\
High & & \\
Perceived barriers & 130 & 56.03 \\
Low & 102 & 43.97 \\
High & & \\
Perceived Benefit & 137 & 59.05 \\
Low & 95 & 40.95 \\
High & & 61.60 \\
Economic Status & 143 & 38.4 \\
S Rp 1,742,000 & 89 & 66.40 \\
R Rp 1,742,000 & & 33.60 \\
Visual Inspection with Acetic Acid & 154 & \\
Undergo & 78 & \\
Not undergo & &
\end{tabular}

\section{Multivariate Analysis}

Multivariate analysis used multilevel multiple logistic regression methods and analyzed using Stata 13. Multivariate analysis explained the effect of more than 1 independent variable on 1 dependent variable.

Table 3 shows that the Community community health center had a contextual influence on VIA uptake with Intra-Class Correlation $(\mathrm{ICC})=16.91 \%$.

VIA uptake increased with high perceived susceptibility $(\mathrm{b}=3.21 ; 95 \% \mathrm{CI}=0.22$ to $6.19 ; \mathrm{p}=0.035)$, high perceived seriousness $(b=4.68 ; 95 \% \mathrm{CI}=1.06$ to $8.29 ; \mathrm{p}=$ o.011), high perceived threat $(b=4.03 ; 95 \%$ $\mathrm{CI}=0.61$ to $7.45 ; \mathrm{p}=0.021$ ), high perceived barrier $(b=2.48 ; 95 \% \mathrm{CI}=0.06$ to $4.91 ; \mathrm{p}=$ 0.044), high perceived benefit $(b=2.50$; 95\% $\mathrm{CI}=0.10$ to $4.91 ; \mathrm{p}=0.041)$, and high economic status $(b=11.22 ; 95 \% \mathrm{CI}=3.64$ to 18.81; $\mathrm{p}=0.004)$.

VIA uptake decreased with low cues to action $(\mathrm{b}=-0.92 ; 95 \% \mathrm{CI}=-3.08$ to $1.24 ; \mathrm{p}=$ 0.405), low self-efficacy $(\mathrm{b}=-0.32 ; 95 \% \mathrm{CI}=$ -2.45 to $1.80 ; \mathrm{p}=0.765$ ), and low social capital $(b=0.79 ; 95 \% \mathrm{CI}=3.64$ to $18.81 ; \mathrm{p}=$ o.562). 
Table 3. Analysis of multilevel multiple logistic regression on the effect of community community health center on VIA uptake

\begin{tabular}{lcccc}
\hline \multirow{2}{*}{ Independent Variables } & b & \multicolumn{2}{c}{ (95\%) CI } & \multirow{2}{*}{ p } \\
\cline { 3 - 4 } Fixed Effect & & Lower limit & Upper limit & \\
Perceived susceptibility (high) & 3.21 & & & \\
Perceived seriousness (high) & 4.68 & 1.06 & 8.19 & 0.035 \\
Cues to action (yes) & -0.92 & -3.08 & 1.24 & 0.011 \\
Perceived threat (strong) & 4.03 & 0.61 & 7.45 & 0.021 \\
Perceived benefit (big) & 2.50 & 0.10 & 4.91 & 0.041 \\
Perceived barriers (big) & 2.48 & 0.06 & 4.91 & 0.044 \\
Self-efficacy (high) & -0.32 & -2.45 & 1.80 & 0.765 \\
Social capital (small) & 0.79 & -1.87 & 3.45 & 0.562 \\
Economic status (high) & 11.22 & 3.64 & 18.81 & 0.004 \\
Random Effect & & & & \\
Community health center & & & & \\
Var (constanta) & 0.67 & & & \\
Log likehood =-21.05 & & & & \\
ICC = 16.91\% & & & & \\
\hline
\end{tabular}

\section{DISCUSSION \\ 1. The effect of community health center on VIA uptake}

Based on the second level analysis, the results obtained by Intra-Class Correlation $(\mathrm{ICC})=16.91 \%$, which means the community health center has an effect on the use of visual inspection of acetic acid. This result is supported by a study by Kholifah (2019) which stated that in his study that the use of VIA screening is affected by Community health center Accreditation with Intra-Class Correlation (ICC) $30.68 \%$.

Community health center (Puskesmas) is one of the health service facilities that is the mainstay or benchmark of health development, a means of community participation, and the first comprehensive service center of an area (Fitriani, 2018).

The reason why there is a difference in the number of VIA by Sulistyo (2019) which screening in each community health center is because of the lack of information regarding VIA screening that are posted on the community health center's wall, distance to the community health center, lack of counseling in villages, and there are several community health centers that have VIA screening rooms that are uncomfortable for patients.

\section{Effects of perceived susceptibility on VIA uptake}

The results showed that there was a positive effect of perceived susceptibility on VIA uptake.

If someone realizes that she is vulnerable or susceptible to a disease, in this case is cervical cancer, she will make an effort to prevent the occurrence of the disease by conducting an VIA screening (Idowu, 2016)

This is in accordance with the HBM theory developed by (MacLaughlin (2011) which stated that the presumption of someone to be easily infected with a disease will make him to do a protection. The results of this study are supported by Sunarta (2019) which stated that there is a corelation between the individual perceived susceptibility and VIA screening.

From the description above it can be concluded that women who have lacking perceived susceptibility will not make an effort to prevent cervical cancer by using the Visual Inspection of Acetic Acid. 
Journal of Health Promotion and Behavior (2019), 4(3): 189-199

https://doi.org/10.26911/thejhpb.2019.04.03.04

\section{Effect of perceived seriousness on VIA uptake}

The results showed that there was a positive effect between perceived seriousness and VIA uptake.

The HBM theory developed by Murti (2018) stated that the perceived seriousness or severity of a disease causes a person to have the attitude to undergo treatment. Marlow (2015) predicted that an individual will take action to protect themselves if they consider that their condition is in serious trouble.

This is supported by the results of Wulandari (2016) that all women of reproductive age assume that cervical cancer is a disease that has a very serious impact. This serious impact is because they believe that cervical cancer sufferers are the same as being sentenced to death.

The treatment is very difficult, requires a long time and the cost is expensive. There is an effect of perceived severity or symptoms that are felt by the willingness to do an VIA screening (Karimy, 2017).

The perceived severity determines whether or not any precautionary measure is taken against this disease in this case cervical cancer, which makes the individual willing to seek information and then use an VIA screening to prevent cervical cancer. This is because they do not want to be affected by the disease so that they will make efforts to prevent the disease.

\section{The effect of perceived threat on VIA uptake}

The results showed that there was a positive effect between perceived threat VIA uptake.

Perceived threat consists of two parts, namely perceived susceptibility to an illness and perceived severity. A person's assumption to be easily infected by a disease will make him to make a protection as well as the attitude to carry out a treatment (Ma, 2013).
Early detection of cervical cancer by VIA screening is carried out so that the disease can be known immediately. So that if the results are positive, abnormal cells in the cervix do not grow into cancer cells. Early detection of cervical cancer needs to be done because the actual development of cervical cancer requires a long time.

\section{The effect of perceived barrier to VIA uptake}

The results showed that there was a positive effect between perceived barrier and VIA uptake.

This is in accordance with a study conducted by Ebu (2016) which stated that there is a significant corelation between perceived barriers with the action of VIA cervical cancer screening method. Wilson (2016) stated that the most common obstacle that women did not screen for was that there were no costs and fear about the results of screening was revealed. It is said by $22.4 \%$ of respondents.

Perceived barrier in VIA screening method makes individuals or women of reproductive age reluctant in conducting such screening. This is due to the many negative assumptions of the individual himself regarding the examination of VIA due to lack of understanding of the benefits of the VIA screening.

\section{The effects of perceived benefit on VIA uptake}

The results showed that there was a positive effect between perceived benefit on VIA uptake.

Ma (2013) stated that the more we know the benefits of cervical examination, the more we can do to do the examination. This is in accordance with the opinion of Kasting (2017) which stated that the benefit of conducting a visual inspection of acetic acid is to detect abnormalities in the cervix immediately after an examination. So, treatment can be done immediately. 
Women who know the benefits of VIA will certainly do the examination so that they will know whether or not they are infected with cervical cancer. The subject of this study has lacking perceived benefits, so that awareness to conduct VIA examination was lacking.

\section{The effect of economic status on the use of VIA screening}

The results showed that there was a positive effect between economic status and VIA uptake.

Economic status is the position of a person or family in the community based on monthly income. Economic status can be seen from income adjusted for prices of basic goods. Family economic status is the economic ability of a family to meet every living need for all family members (Wakhidah, 2017).

Saptowati (2018) also stated that there is still an assumption that women have weak, dependent, and not independent access, for example to family finances, thereby reducing their ability to protect themselves from disease risk factors. Also, even if they are sick women must obtain their husband's permission to visit health care facilities.

Limited money, distance/ transportation, information and technology worsens the condition of women to do VIA screening. If women have access to finance, independent decisions will have a significant impact on women's well-being (Jia, 2013).

Economic status is an obstacle for some respondents because the salary that is just average makes them afraid to do an VIA screening which is considered to be expensive.

\section{AUTHOR CONTRIBUTION}

Retno Wulan as the main researcher implemented the study, conducted the study interventions, formulate research articles, and data processing. Pawito formulated of the mindset in the study. Bhisma Murti formulated of methods of the study and the discussion of results of the study.

\section{FUNDING AND SPONSORSHIP}

The study used personal fund from the main researcher.

\section{CONFLICT OF INTEREST}

There was no conflict of interest in this study.

\section{ACKNOWLEDGEMENT}

The researchers would like to thank the Head of Community health center in Pati, Central Java who had allowed this research to be carried out. We also would like to thank to all women of childbearing age who had been cooperative as the subjects of this study.

\section{REFERENCE}

Central Java Province Health Office. (2017). Profil kesehatan provinsi jawa tengah 2017. https://doi.org/10.56o6/totbid.dergisi.2012.10

Ebu NI, Mupepi SC, Siakwa MP, Sampselle CM (2016). Knowledge, practice, and barriers toward cervical cancer screening in Elmina, Southern Ghana. Int J Womens Health. 24(7):31-9. doi: 10.2147/IJWH.S71797.

Fitriani Y, Mudigdo A, Adriani RB (2018). Health belief model on the determinants of human papilloma virus vaccination in women of reproductive age in Surakarta, Central Java. J Health Promot Behav, 03(01): 16-26. https://doi.org/10.26911/thejhpb.2018.03.01.02.

Idowu A, Olowookere SA, Fagbemi AT, 
Journal of Health Promotion and Behavior (2019), 4(3): 189-199

https://doi.org/10.26911/thejhpb.2019.04.03.04

Ogunlaja OA (2016). Determinants of cervical cancer screening uptake among women in Ilorin, North Central Nigeria: A Community-Based Study. Journal of Cancer Epidemiology. Retrieved from: https://doi.org/10$.1155 / 2016 / 6-469240$.

Jia Y, Li S, Yang R, Zhou H, Xiang Q, Hu T, Feng L (2013). Knowledge about cervical cancer and barriers of screening program among women in Wufeng Country, a High-Incidence Region of Cervical Cancer in China. PLoS ONE, 8(7): 2-8. https://doi.org/10.1371/journal.pone.0067005.

Karimy M, Azarpira H, Araban M (2017). Using health belief model constructs to examine differences in adherence to pap test recommendations among Iranian Women. Asian Pacific Journal of Cancer Prevention: APJCP, 18(5): 1389-1394. https://doi.org/10.22034/APJCP.2017.18.5.1389.

Kasting ML, Wilson S, Zollinger TW, Dixon BE, Stupiansky NW, Zimet GD (2017). Differences in cervical cancer screening knowledge, practices, and beliefs: An examination of survey responses. Preventive Medicine Reports: 169174. Retrieved from: https://doi.org/10.1016/j.pmedr.2016.12.013

Kementerian Kesehatan RI (2018). Hasil Utama Riskesdas Tahun 2018. Hlm. 51. Retreived from: http://www.depkes.go.id.

Kholifah S, Budihastuti UR, Murti B (2019). Factors affecting the use of visual inspection acetic acid test: multilevel analysis on the contextual effect of community health center. J Health Promot Behav, 4(1): 1-11. https://doi.org/10.26911/thejhpb.2019.04.01. 01.

MacLaughlin KL, Angstman KB, Flynn PM, Schmit JR, Weaver AL, Shuster LT
(2011). Predictors of patient comfort and adherence with less frequent cervical cancer screening. Quality in Primary Care. 19(6): 355-363. doi:10.13140/RG.2.1.2605.6800.

Ma GX, Gao W, Fang CY, Tan Y, Feng Z, Ge S, Nguyen JA (2013). Health beliefs associated with cervical cancer screening among Vietnamese Americans. Journal of Women's Health, 22(3): 276-288. https://doi.org/10.1089/jwh.2012.3587

Marlow L, Waller J, Wardle J (2015). Barriers to cervical cancer screening among ethnic minority women: a qualitative study. The Journal of Family Planning and Reproductive Health Care/Faculty of Family Planning \& Reproductive Health Care, Royal College of Obstetricians \& Gynaecologists, 41(4): 248-254. https://doi.org/10.1136/jfprhc-2014- 101082 .

Murti B (2016). Prinsip dan metode riset epidemiologi. Program studi ilmu kesehatan masyarakat program pascasarjana universitas sebelas maret: yuma pustaka.

Murti B (2018). Teori Promosi dan perilaku kesehatan. Surakarta: Master Program of Public Health.

Saptowati D, Mudigdo A, Murti B (2018). Biopsychosocial determinants of visual inspection acetic-acid test uptake in Sragen, Central Java. J Matern Child Health, 03(03): 197-206. https://doi.org/10.26911/thejmch.2018.03.03 .04

Saraswati M, Ayun S, Sutopo P (2017). Analaisis Implementasi Program Deteksi Dini Kanker Serviks Melalui Metode Inspeksi Visual Asam Asetat (IVA) di Puskesmas Kota Semarang. JKM, 05(04):85-94. Retreived from: https//ejournal3.undip.ac.id/index.p $\mathrm{hp} / \mathrm{jkm} /$ article/view/18320 
Sulistyo SA, Tamtomo D, Sulaeman ES (2019). Accreditation status and other factors affecting patient satisfaction in hospital. J Health Policy Manage, 4(3): 139-149. https://doi.org/10.26911/thejhpm.2019.04.03.01.

Sunarta E, Sulaeman E, Budihastuti U (2019). Path analysis on the determinants of visual inspection acetic acid utilization on early detection of cervical cancer: application of health belief model theory. J Health Promot Behav, 04(01): 32-42. https://doi.org/10.26911/thejhpb.2019.04.01.04.

Wakhidah MS, Budihastuti UR, Dewi YLR (2017). The influence of personal factor, husband's support, health workers and peers toward the use of iva screening among women of reproductive age in the Regency of Karanganyar. J Health Promot Behav, 2(2): 124-137. https://doi.org/10.26911/thejhpb.2017.02.02.03.

WHO (2018). Human Papillovirus and cer- vical cancer. Retrieved from https://www.who.int/en/news-room/factsheets/detail/human-papillomavirus(hpv)-and-cervical-cancer.

Wilson AR, Hashibe M, Bodson J, Gren LH, Taylor BA, Greenwood J, et al. (2016). Factors related to HPV vaccine uptake and 3-dose completion among women in a low vaccination region of the USA: An observational study. BMC Women's Health. BMC Women's Health, 16(1): 1-9. doi: 10.1186/s12905-016-0323-5.

Wulandari YA, Suryani N, Pamungkasari EP (2016). Health belief model: Health preventive behavior of sexually transmitted infection in female sex workers in Surakarta. J Health Promot Behav, 01(02): 70-78. https://doi.org/10.26911/thejhpb.2016.01.02. 02. 